\title{
Exploring the effect of composting technologies on the recovery of hydrocarbon contaminated soil post chemical oxidative treatment
}

\author{
Rocío Medina ${ }^{\mathrm{a}, \mathrm{b}, 1}$, Antonio J. Fernández-González ${ }^{\mathrm{c}}$, Fernando M. García-Rodríguez ${ }^{\mathrm{c}}$, \\ Pablo J. Villadas ${ }^{\mathrm{c}}$, Janina A. Rosso ${ }^{\mathrm{b}}$, Manuel Fernández-López ${ }^{\mathrm{c}}$, María T. Del Panno ${ }^{\mathrm{a}, *}$ \\ ${ }^{a}$ Centro de Investigación y Desarrollo en Fermentaciones Industriales (CINDEFI) CONICET- UNLP, La Plata, Buenos Aires, Argentina \\ ${ }^{\mathrm{b}}$ Instituto de Investigaciones Fisicoquímicas Teóricas y Aplicadas (INIFTA) CONICET- UNLP, La Plata, Buenos Aires, Argentina \\ ${ }^{\mathrm{c}}$ Estación Experimental del Zaidín, Consejo Superior de Investigaciones Científicas (CSIC), Granada, Spain
}

Polycyclic aromatic hydrocarbons (PAHs) are ubiquitous organic pollutants that contaminate large areas. They are mainly released to environment by anthropogenic activities principally due to the petrochemical industry. The low biodegradation rate characteristic of PAHs in aged contaminated soils could be overcome trough the chemical oxidation. In this study, composting with the soil and stimulation with mature compost were the strategies applied in soil microcosms after chemical oxidation with ammonium persulfate in a PAHs chronically contaminated soil.

A $29 \%$ of PAHs elimination and an increase of their bioavailability were found after chemical oxidation with ammonium persulfate. Due to the oxidative treatment the total bacterial and the gram-positive population PAH dioxygenase genes were significantly reduced and no gram-negative PAHs degraders were detected.

The following application of organic amendments produced a higher increase in total bacteria and recovery of the degrading population of GP PAH after one year of treatment, in comparison with the pre-oxidized soil bioremediation, only promoted by irrigation and aeration. Also a significant increase in the content of bioavailable PAHs was observed. However, from both composting strategies only the stimulation with mature compost led to a net PAHs removal. Taking into account the residual dissolved total carbon and humification degree $\left(\mathrm{E}_{4} / \mathrm{E}_{6}\right.$ ratio), it was attributed to the preferential consumption of more easily degradable compounds than hydrocarbons the low removal efficiency observed after one year of treatment.

Due to the high bioavailable content of PAH and the residual sulfate, long-term treatments will require careful monitoring to reduce environmental risks.

\section{Introduction}

The Status of the World's Soil Resources Report identified soil pollution as one of the main soil threats affecting global soils (RodríguezEugenio et al., 2018).

One of the main anthropogenic sources of soil pollution is pollutants associated with petroleum and petrochemical activities (Lemaire et al., 2013). Of these pollutants polycyclic aromatic hydrocarbons (PAHs) constitute one of the most important groups of organic compounds. The PAHs are comprised of two or more fused benzene rings which are strongly hydrophobic and chemically stable (Fetzer, 2007). These properties reduced their degradation and consequently result in their accumulation in long-term contaminated sites. Due to its recalcitrance and strong mutagenic/carcinogenic properties, this pollutant group is of great concern for human health and the environment (Suman et al., 2016; Wang et al., 2017).

In this context, the development of remediation technologies for organic-contaminated soil is a priority to protect public health and the environment. Although several soil microorganisms are capable of metabolizing PAHs, their low mass transfer and reduced availability in the soil make the design of effective bioremediation strategies a challenge (Cai et al., 2007; Sayara et al., 2009). As a result, a great number

\footnotetext{
Abbreviations: PAH-RHD $\alpha-G N$, alpha subunit of dioxygenase genes of PAH-Gram negative bacteria; PAH-RHD $\alpha$-GP, alpha subunit of dioxygenase genes of PAH-

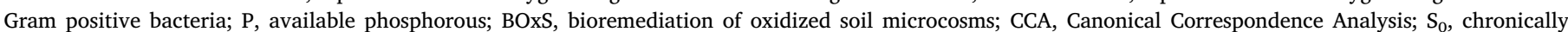

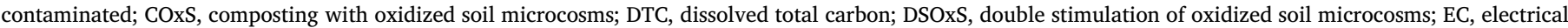

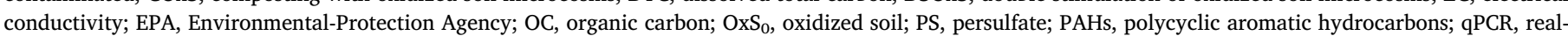
time quantitative PCR; OPR, redox potential; SOM, soil organic matter; S, sulfate content; N, total nitrogen

* Corresponding author.

E-mail addresses: antonio.fernandez@eez.csic.es (A.J. Fernández-González), fgarcia@eez.csic.es (F.M. García-Rodríguez), pablo.villadas@eez.csic.es (P.J. Villadas), manuel.fernandez@eez.csic.es (M. Fernández-López), tere@biol.unlp.edu.ar (M.T. Del Panno).

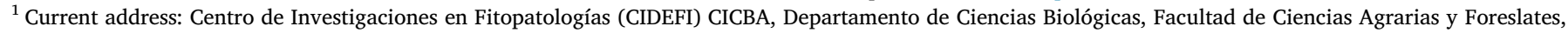
UNLP, La Plata, Buenos Aires, Argentina
} 
of chemically-based strategies for soil remediation have been successfully implemented to reduce PAH pollution. Of these, oxidative treatments appear to have the greatest effect on PAHs availability (Mora et al., 2014; Sutton et al., 2014a; Medina et al., 2018).

Among several oxidants (permanganate, ozone and Fenton's reagent ( $\mathrm{Fe}(\mathrm{II})-\mathrm{H}_{2} \mathrm{O}_{2}$ ), persulfate (PS) has increasingly been used over the last few decades (Mora et al., 2014; Kakosová et al., 2017; Medina et al., 2018; Peluffo et al., 2018). Some of its properties, such as ease of handling, high aqueous solubility, high stability and relatively low cost give it a competitive advantage to be selected as an emerging oxidant for In Situ Chemical Oxidation (Liang et al., 2003; Huling and Pivetz, 2006; Lominchar et al., 2017).

Persulfate decomposition can be initiated by heat, UV light, high $\mathrm{pH}$ or transition metals, generating sulfate radical $\left(\mathrm{SO}_{4}^{-*}\right)$ (Osgerby, 2006; Tsitonaki et al., 2010) which can react with not only available contaminants, but also the soil organic matter and the soil microbial community (Sutton et al., 2011; Zhou et al., 2019). Although oxidant addition is an aggressive treatment for the microbial community, the application of an oxidant could increase the efficiency of hydrocarbon removal when followed by bioremediation treatment. Therefore, the partial chemical oxidation facilitates the biodegradability of contaminants, generally through the cleavage of large organic compounds into smaller ones (Valderrama et al., 2009; Liao et al., 2019). The compounds released during the partial oxidation can then be assimilated by populations resistant to the oxidative stress, allowing the soil to recover.

The combination of persulfate oxidation with biological treatment can be a promising strategy. Medina et al. (2018) applied an oxidative treatment with low concentration of ammonium persulfate under unsaturated conditions in an aged PAHs contaminated soil which led to the PAHs removal and the increase in the content of available PAH along with the mobilization of the soil nutrients. After one year of biological treatment, additional PAHs and total aliphatic hydrocarbon were eliminated. In a field experiment, Bajagain et al. (2018) showed that bioremediation after using a persulfate foam spraying technique removed $77 \%$ of total hydrocarbons in diesel-contaminated unsaturated soil.

Composting has been a successful bioremediation strategy in soils contaminated with PAHs, as well as with other pollutants, by providing organic substrates that stimulate the growth of potential microbial degraders and enhancing soil properties and quality (Antízar-Ladislao et al., 2006; Scelza et al., 2008; Covino et al., 2016; Jednak et al., 2017; Cipullo et al., 2019; Liu et al., 2019). However, few studies have considered composting or the addition of organic matter amendments to stimulate the microbial soil community, as a bioremediation strategy applied after the oxidative step (Satapanajaru et al., 2017).

The distribution of PAHs in soil is strongly affected by the organic matter. Humic acids from the dissolved organic matter are mainly involved in the storage and degradation mechanism of pollutants in soil (Liao et al., 2019). Depending on the way in which the PAHs are available, free crystals or associated to solid phase, the dissolved humic acids may cause no effect, stimulation or inhibition on the biodegradation of PAHs (Tejeda-Agredano et al., 2014). In addition, the aliphatic content of the dissolved organic matter was suggested to play a more important role in sorption of PAHs (Ilani et al., 2005). Even though these findings make difficult to predict the effect of organic amendment, it might provide an alternative strategy to recover the oxidized soil matrix after persulfate treatment.

To evaluate the efficiency of combined treatments on PAHs elimination, persulfate oxidation followed by composting or stimulation with mature compost was applied to a chronically PAH contaminated soil.

It was hypothesized that composting strategies applied after oxidation with persulfate allow for a more efficient recovery of the potential PAH degrading capacity and soil microbial diversity, enhancing the effect of the oxidative treatment followed by bioremediation only promoted by irrigation and aeration.

To test this hypothesis, we evaluated hydrocarbon elimination, nutrient mobilization, bacterial diversity and recovery of the potential PAH degrading capacity of the bacterial community after the combined treatments.

\section{Materials and methods}

\subsection{Site description and sample collection}

The chronically contaminated soil used in this work was described in previous studies (Medina et al., 2018). The soil, $\mathrm{S}_{0}$, was sampled from a landfarming unit belonging to a petrochemical industry in La Plata city, specifically from the geographical localization $34^{\circ} 53^{\prime} 19^{\prime \prime}$, $57^{\circ} 55^{\prime} 38^{\prime \prime} \mathrm{W}$, where the landfarming treatment had been completed about twenty years before. The soil was classified as loam (sand $44.4 \%$, silt $40.0 \%$, and clay $15.6 \%$ ) and its water holding capacity was $27.45 \%$. The sampled soil was treated with ammonium persulfate $\left(33 \mathrm{~g} \cdot \mathrm{kg}^{-1}\right)$ to obtain the oxidized soil, $\mathrm{OxS}_{0}$, as it was previously described by Medina et al. (2018).

\subsection{Soil treatments}

The oxidized soil $\left(\mathrm{OxS}_{0}\right)$ was then treated by composting (COxS), or stimulation with mature compost in soil microcosms (DSOxS). The oxidized soil without any organic amendment was used to prepare the control soil microcosms (BOxS). All treatments were assayed by triplicated microcosms. Each treatment is presented in the Scheme 1.

\subsubsection{Composting treatment (COxS)}

A subsample of $\mathrm{OxS}_{0}$ was conditioned with goat manure in ratio $7 \mathrm{~g}$ dry soil: $3 \mathrm{~g}$ dry goat manure (Antízar-Ladislao et al., 2006). A bulking agent (oat straw) was added to the resulting mixture at a ratio of $1: 1 \mathrm{v} / \mathrm{v}$ to provide a proper porosity and maintain aerobic conditions, such as

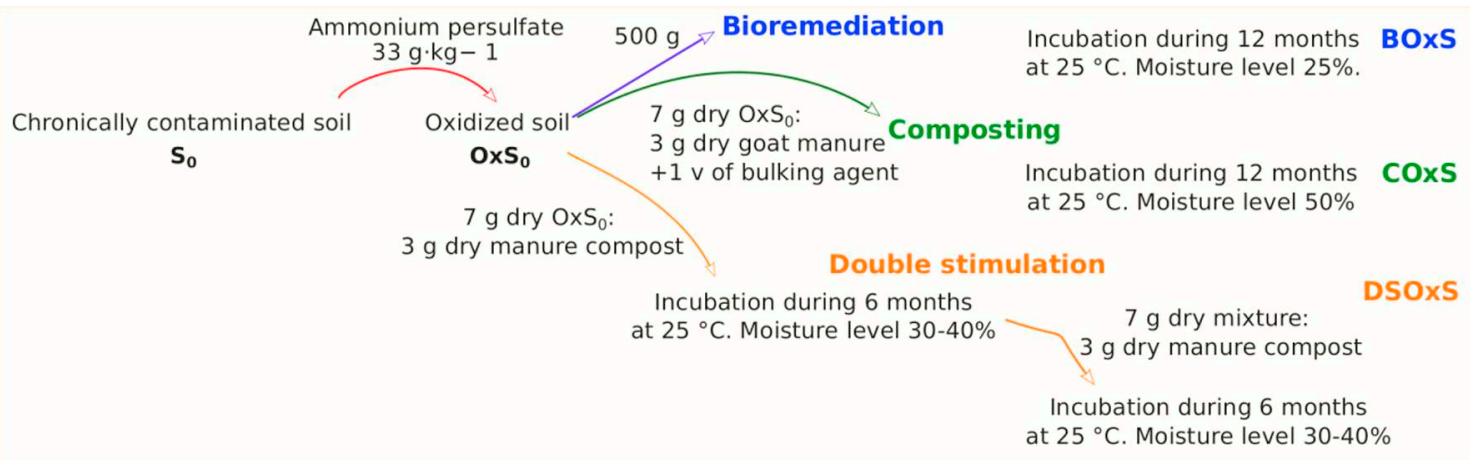

Scheme 1. Scheme of the sequence of chemical and biological treatments applied to the chronically contaminated soil. 
described by Antízar-Ladislao et al. (2006). About $2 \mathrm{~kg}$ of the mixture was introduced into three glass reactors. The microcosms were incubated at $25{ }^{\circ} \mathrm{C}$ for 12 months. Moisture level was maintained at $50 \%$ $w / \mathrm{w}$ by periodic watering.

\subsubsection{Double stimulation treatment (DSOxS)}

About $500 \mathrm{~g}$ of $\mathrm{OxS}_{0}$ was amended with mature compost, at mixing ratio $7 \mathrm{~g}$ dry soil: $3 \mathrm{~g}$ dry mature compost. Microcosms were prepared with $500 \mathrm{~g}$ of resulting mixture and were incubated at $25{ }^{\circ} \mathrm{C}$ with the moisture content adjusted at $30-40 \% \mathrm{w} / \mathrm{w}$. After six months of treatment, the microcosms were again supplemented with the same proportion of mature compost, remaining incubated for another six months at the same conditions described above.

\subsubsection{Bioremediation treatment (BOxS)}

A $500 \mathrm{~g}$ of $\mathrm{OxS}_{0}$ was incubated at $25{ }^{\circ} \mathrm{C}$ during 12 months as previously described (Medina et al., 2018). These microcosms were used as controls of amendment treatments.

\subsection{Soil analysis}

A sample (2.5 g) was suspended in $2.5 \mathrm{ml}$ of water, shake for $1 \mathrm{~h}$, and decanted along $10 \mathrm{~min}$ in order to measure $\mathrm{pH}$, electrical conductivity (EC), redox potential (OPR) as described by Mora et al. (2014). According to the protocols described by Sparks (1996): Walkley-Black method was performed for organic carbon (OC) determination, wet digestion and evaluation by Micro Kjendahl method were applied for total nitrogen $(\mathrm{N})$ measure, Bray Kurtz no. 1 method was done for available phosphorous (P) determination, and sulfate content (S) was measured according to SAMLA SAGPyA 2004 method. Total iron and available iron were measured according to EPA 3050b and EPA 7950 methods, respectively.

The soil organic matter (SOM) was extracted according to Swift (1996) with minor modifications as described in a previous work (Medina et al., 2018). These extracts were used for absorption-spectra analysis $\left(\mathrm{E}_{4} / \mathrm{E}_{6}\right.$ ratio) and determination of the dissolved total carbon (DTC) that was measured with a Total Organic Carbon Analyser Shimadzu, TOC5000 (Mora et al., 2009).

To determine PAHs and AHs concentrations, soil extraction with acetone/dichlorometane (1/1, v/v) as the solvent (Sayara et al., 2010), by ultrasonic bath for $60 \mathrm{~min}$ (Testlab Ultrasonic TB04TA, $40 \mathrm{kHz}$, $160 \mathrm{~W}$ ) was performed according to Environmental-Protection Agency (EPA) method 3550b. Bioavailable PAH fraction was determined as described by Cébron et al. (2013), using XAD2 resin being used as the sorbent. PAH and AH quantities were analysed from the extracts by a gas chromatograph (Clarus 500, Perkin Elmer) equipped with a flameionization detector and a 5HT PE column as described by Medina et al. (2018).

All measurements were done by triplicate individual samples for statistical analysis and the results were shown by kg of dry soil.

\subsection{Genomics analysis}

\subsubsection{DNA extraction}

Total DNA extraction and quantification were made as described in previous studies (Medina et al., 2018) using the E.Z.N.A. ${ }^{\mathrm{m}}{ }^{\mathrm{M}}$ Soil DNA Isolation Kit (Omega Bio-tek, Inc., Norcross, GA, USA) and the QuantiT $^{\mathrm{TM}}$ PicoGreen ${ }^{\circledR}$ dsDNA Assay Kit (Invitrogen ${ }^{\mathrm{TM}}$, Carlsbad, CA, USA).

\subsubsection{Total population and PAH dioxygenase genes population}

Real-time quantitative PCR (qPCR) was performed to measure the abundance of total bacterial 16S rRNA genes and dioxygenase genes of both PAH-Gram negative (PAH-RHD $\alpha-G N)$ and PAH-Gram positive $(P A H-R H D \alpha-G P)$ degrading bacteria respectively.

The gene amplification was carried out optimizing the corresponding primer sets (Table S1) with a gradient of annealing temperature (from 45 to $65{ }^{\circ} \mathrm{C}$ ) with template DNA from $\mathrm{S}_{0}$. PCR reactions were performed as described by Cébron et al. (2008), using an Eppendorf 5331 MasterCyclerGradient Thermal Cycler. Amplified fragments were visualized and compared with $\varnothing 29$ HindIII digested DNA (4370 to $72 \mathrm{bp}$ ) marker on $2 \% \mathrm{w} / \mathrm{w}$ agarose gels stained with GelRed.

qPCR was performed as described in Supplementary Material (S1) using the iCycler iQ system (Bio-Rad). Dilution series from $10^{-8}$ to $10^{-1}$ copy were made for quantitative analysis. Values of threshold cycles (Ct) were determined and target gene copy number in the samples was calculated from standard curves. No PCR inhibitors were detected and the purity of amplified PCR products was checked as described by Cébron et al. (2008) and Sun et al. (2015). Results were expressed as copy number per $\mathrm{g}$ dry soil.

\subsubsection{Cloning of $P A H-R H D \alpha$ genes}

Clones were generated from $\mathrm{S}_{0}$. PAH-RHD $\alpha$-GN and PAH-RHD $\alpha$-GP amplicons were obtained as described above, and PCR products were cleaned by centrifugation on IllustraMicroSpin ${ }^{\mathrm{TM}} \mathrm{S}-300 \mathrm{HR}$ columns (GE Healthcare) according to the manufacturer's instructions. The purified amplicons were then ligated into the pGEM-T Easy vector (Promega) and used to transform Escherichia coli strain DH5a (Villadas et al., 2007). Positive bacterial colonies were randomly selected, and the sizes of the inserts were checked by PCR amplification with T7 and SP6 promoter primers and gel electrophoresis, as previously described. Clones were sequenced by Sanger method (Sanger et al., 1977), with an ABI Prism 3130XL at Estación Experimental del Zaidín, CSIC (Granada, Spain). Raw sequence data were processed in Sequence Scanner version 1.0. Sequence alignments were generated on the BioEdit (v7.0.9) software (Hall, 1999).

\subsubsection{Community structure and diversity}

DNA samples of $\mathrm{S}_{0}, \mathrm{OxS}_{0}$ and from the finished treatments (COxS, DSOxS and BOxS) were used for PCR amplification of the hypervariable regions of the 16S rRNA gene with universal primers U519F and U926R (Baker et al., 2003) to amplify a 407-bp fragment of this gene flanking the V4 and V5 regions as described by Curiel-Yuste et al. (2012), Table S1, See Supplementary Material S2). The samples were pyrosequenced with the Genome Sequencer GS Junior system (454 Life Sciences, Branford, CT, USA) at Estación Experimental del Zaidín, CSIC (Granada, Spain). The sff files were submitted to the NCBI Sequence Read Archive (http://www.ncbi.nlm.nih.gov/sra) and are available (BioProject: PRJNA306241).

The pyrosequencing data were analysed, clustered and classified using the Mothur software (version v.1.34.0; Schloss et al., 2009) according to the methodology described by Fernández-González et al. (2017). As normalization step, prior to diversity analysis, was done using a randomly subsampling to the lowest number of sequences produced from any sample. The Good's coverage estimate (Jost, 2006; Chao et al., 2012) was calculated as described by Medina et al. (2018) and alpha diversity was analysed through Hill's numbers: species richness $\left[{ }^{0} \mathrm{D}\right]$, the exponential of the Shannon diversity index $\left[{ }^{1} \mathrm{D}\right]$ and the reciprocal of Simpson's index $\left[{ }^{2} \mathrm{D}\right]$ (Hill, 1973).

\subsection{Statistical analyses}

The effect on the physical, chemical as well as molecular studies evaluated during the treatments was interpreted by an analysis of variance (ANOVA) after the Tukey test with XLStat (v.7.5.2), at a significance threshold of $p<.05$.

In order to evaluate the physical and chemical parameters and their relationships with the microbial community Canonical Correspondence Analysis (CCA) using Canoco for windows (v 4.5) was performed. For this purpose, pH, EC, OPR, OC, N, P, sulfate, AHs, PAHs and bioavailable fraction of PAH as chemical and physical variables, and taxonomical order level using the orders with a relative abundance $>2 \%$ were included into the analysis. 
Table 1

Chemical and physical properties of the soil microcosms before and after the treatments.

\begin{tabular}{|c|c|c|c|c|c|}
\hline & $\mathrm{S}_{0}$ & $\mathrm{OxS}_{0}$ & BOxS & COxS & DSOxS \\
\hline $\mathrm{pH}$ & $\begin{array}{l}8.8 \pm 0.1 \\
\text { (a) }\end{array}$ & $\begin{array}{l}7.1 \pm 0.1 \\
\text { (b) }\end{array}$ & $\begin{array}{l}6.3 \pm 0.1 \\
\text { (d) }\end{array}$ & $\begin{array}{l}6.2 \pm 0.1 \\
\text { (d) }\end{array}$ & $\begin{array}{l}6.6 \pm 0.1 \\
\text { (c) }\end{array}$ \\
\hline $\mathrm{EC}\left[\mathrm{dS} \mathrm{m} \mathrm{m}^{-1}\right]$ & $\begin{array}{l}0.63 \pm 0.01 \\
\text { (e) }\end{array}$ & $\begin{array}{l}5.1 \pm 0.1 \\
\text { (d) }\end{array}$ & $\begin{array}{l}5.9 \pm 0.4 \\
\text { (c) }\end{array}$ & $\begin{array}{l}8.52 \pm 0.08 \\
\text { (b) }\end{array}$ & $\begin{array}{l}11.4 \pm 0.1 \\
\text { (a) }\end{array}$ \\
\hline $\mathrm{OPR}[\mathrm{mV}]$ & $\begin{array}{l}236 \pm 2 \\
\text { (d) }\end{array}$ & $\begin{array}{l}291 \pm 2 \\
\text { (a) }\end{array}$ & $\begin{array}{l}270.6 \pm 0.3 \\
\text { (b) }\end{array}$ & $\begin{array}{l}259 \pm 2 \\
\text { (c) }\end{array}$ & $\begin{array}{l}261 \pm 6 \\
(c)\end{array}$ \\
\hline OC [\%] & $\begin{array}{l}2.2 \pm 0.8 \\
\text { (c) }\end{array}$ & $\begin{array}{l}2.4 \pm 0.1 \\
(c)\end{array}$ & $\begin{array}{l}2.6 \pm 0.1 \\
(c)\end{array}$ & $\begin{array}{l}10.9 \pm 0.3 \\
\text { (b) }\end{array}$ & $\begin{array}{l}12.9 \pm 0.3 \\
\text { (a) }\end{array}$ \\
\hline $\mathrm{N}\left[\mathrm{mg} \mathrm{kg}^{-1}\right]$ & $\begin{array}{l}0.2 \pm 0.1 \\
(\mathrm{c})\end{array}$ & $\begin{array}{l}0.50 \pm 0.01 \\
\text { (b) }\end{array}$ & $\begin{array}{l}0.30 \pm 0.04 \\
(c)\end{array}$ & $\begin{array}{l}1.12 \pm 0.06 \\
\text { (a) }\end{array}$ & $\begin{array}{l}1.11 \pm 0.01 \\
\text { (a) }\end{array}$ \\
\hline $\mathrm{P}\left[\mathrm{mg} \mathrm{kg}^{-1}\right]$ & $\begin{array}{l}8.3 \pm 0.6 \\
(\mathrm{e})\end{array}$ & $\begin{array}{l}14.5 \pm 0.7 \\
\text { (d) }\end{array}$ & $\begin{array}{l}22.0 \pm 0.1 \\
\text { (c) }\end{array}$ & $\begin{array}{l}316.0 \pm 0.3 \\
\text { (b) }\end{array}$ & $\begin{array}{l}328.0 \pm 0.1 \\
\text { (a) }\end{array}$ \\
\hline $\mathrm{Fe}\left[\mathrm{mg} \mathrm{kg}^{-1}\right]$ & $\begin{array}{l}12.6 \pm 0.3 \\
\text { (b) }\end{array}$ & $\begin{array}{l}54 \pm 2 \\
\text { (a) }\end{array}$ & nd & nd & nd \\
\hline Sulfate $\left[\mathrm{mg} \mathrm{kg}^{-1}\right]$ & $\begin{array}{l}97 \pm 6 \\
\text { (e) }\end{array}$ & $\begin{array}{l}8407 \pm 16 \\
\text { (a) }\end{array}$ & $\begin{array}{l}4894 \pm 15 \\
\text { (b) }\end{array}$ & $\begin{array}{l}3957 \pm 30 \\
\text { (c) }\end{array}$ & $\begin{array}{l}3120 \pm 16 \\
\text { (d) }\end{array}$ \\
\hline $\mathrm{DTC}\left[\mathrm{mgC} 1^{-1}\right]$ & $96 \pm 3(\mathrm{c})$ & $226 \pm 2(a)$ & $57 \pm 2(\mathrm{e})$ & $62.2 \pm 0.1(\mathrm{~d})$ & $189 \pm 3(b)$ \\
\hline $\mathrm{E}_{4} / \mathrm{E}_{6}$ & 15 & 17.7 & 7.1 & 23 & 3.8 \\
\hline
\end{tabular}

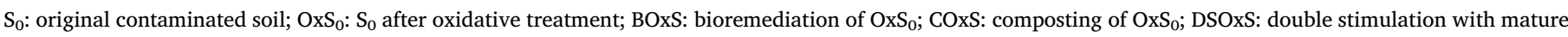
compost of $\mathrm{OxS}_{0}$.

nd: not determined.

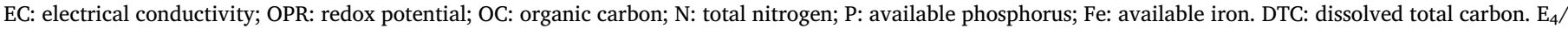

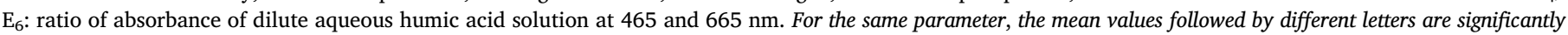
different $(p<.05)$

\section{Results}

\subsection{Effect of the amendment on the chemical and physical properties and} hydrocarbon elimination of the pre-oxidized soil

Physical and chemical properties and hydrocarbon content of soil are shown in Table 1 and Table 2.

Available iron content in $S_{0}\left(12.6 \pm 0.3 \mathrm{mg} \mathrm{kg}^{-1}\right.$, Table 1) was enough to PS activation, as reported in previous studies (Medina et al., 2018). The oxidative treatment with PS $\left(\mathrm{OxS}_{0}\right)$ produced a significant increase in DTC, EC, $\mathrm{N}, \mathrm{P}, \mathrm{Fe}$, and sulfate with a decrease in the $\mathrm{pH}$ value (Table 1). The elimination of $29 \%$ of PAHs content along the release of high molecular weight PAHs from the matrix soil, and the rising of their bioavailability were observed (Table 2) as discussed previously (Medina et al., 2018).

BOxS control treatment, without organic amendments added, produced a decrease in the $\mathrm{pH}$ value, DTC, $\mathrm{N}$ and sulfate contents; while an increase in EC and P content were observed (Table 1). In addition, a significant decrease in the $\mathrm{E}_{4} / \mathrm{E}_{6}$ rate from the soil extracts was observed in this treatment. The BOxS treatment following the oxidative treatment produced an additional PAHs elimination of about $26 \%$ along with an increase in the bioavailable fraction (Table 2). A significant elimination of AHs of around $66 \%$ was also detected with the decrease in the $\mathrm{C}_{9}-\mathrm{C}_{20}$ fraction, as reported in previous studies (Medina et al., 2018).

As BOxS, composting (COxS treatment) and stimulation with mature compost (DSOxS treatment) led to acidic $\mathrm{pH}$ probably due to the microbial activity. As expected, when composting strategies were applied, an increase of OC, $\mathrm{N}$ and $\mathrm{P}$ contents was observed, due to the nature of the amendment used. However, a significant reduction in the DTC values was detected after the composting strategies. Only after the DSOxS treatment a decrease of the $\mathrm{E}_{4} / \mathrm{E}_{6}$ ratio from the soil extracts was observed.

The organic amendment also increased the EC to values higher than $\mathrm{OxS}_{0}$. Sulfate reduction of $53 \%$ by COxS and of $63 \%$ by DSOxS treatments was detected after the year (Table 1). Taken into account the reduction produced by the amendments ( $65 \%$ by composting and $51 \%$ by double stimulation), only the stimulation treatment with mature

Table 2

Content of hydrocarbons in each soil microcosm.

\begin{tabular}{|c|c|c|c|c|c|c|}
\hline & $\mathrm{S}_{0}$ & $\mathrm{OxS}_{0}$ & BOxS & $\mathrm{COxS}$ & DSOxS & Compost \\
\hline $\begin{array}{l}\text { polycyclic aromatic hydrocarbons (PAHs) } \\
{\left[\mathrm{mg} \mathrm{kg}^{-1}\right]}\end{array}$ & $\begin{array}{l}214 \pm 21 \\
\text { (a) }\end{array}$ & $\begin{array}{l}151 \pm 12 \\
\text { (b) }\end{array}$ & $\begin{array}{l}112 \pm 4 \\
\text { (c) }\end{array}$ & $\begin{array}{l}100 \pm 24 \\
\text { (c) }\end{array}$ & $\begin{array}{l}58 \pm 6 \\
\text { (d) }\end{array}$ & nd \\
\hline 3-ring $[\%]$ & 36 & 27 & 18 & 18 & 15 & - \\
\hline 4-ring $[\%]$ & 48 & 49 & 54 & 52 & 53 & - \\
\hline 5-ring $[\%]$ & 6 & 6 & 10 & 11 & 22 & - \\
\hline 6-ring [\%] & 10 & 18 & 18 & 19 & 10 & - \\
\hline Available PAHs [\%] & $\begin{array}{l}1 \pm 1 \\
\text { (d) }\end{array}$ & $\begin{array}{l}19 \pm 4 \\
(c)\end{array}$ & $\begin{array}{l}30 \pm 2 \\
\text { (b) }\end{array}$ & $\begin{array}{l}56 \pm 4 \\
\text { (a) }\end{array}$ & $\begin{array}{l}54 \pm 4 \\
\text { (a) }\end{array}$ & - \\
\hline $\begin{array}{l}\text { Total aliphatic hydrocarbons } \\
\qquad\left[\mathrm{g} \mathrm{kg}^{-1}\right]^{\dagger}\end{array}$ & $\begin{array}{l}2.4 \pm 0.2 \\
\text { (a) }\end{array}$ & $\begin{array}{l}2.4 \pm 0.2 \\
\text { (a) }\end{array}$ & $\begin{array}{l}0.8 \pm 0.2 \\
(c)\end{array}$ & $\begin{array}{l}0.79 \pm 0.02 \\
\text { (c) }\end{array}$ & $\begin{array}{l}1.3 \pm 0.1 \\
\text { (b) }\end{array}$ & $\begin{array}{l}2.4 \pm 0.2 \\
\text { (a) }\end{array}$ \\
\hline $\mathrm{C}_{9}-\mathrm{C}_{20}[\%]$ & 53 & 49 & 22 & 17 & 21 & 41 \\
\hline $\mathrm{C}_{20}-\mathrm{C}_{29}[\%]$ & 42 & 43 & 69 & 56 & 41 & 35 \\
\hline $\mathrm{C}_{29}-\mathrm{C}_{35}[\%]$ & 5 & 8 & 9 & 27 & 38 & 24 \\
\hline
\end{tabular}

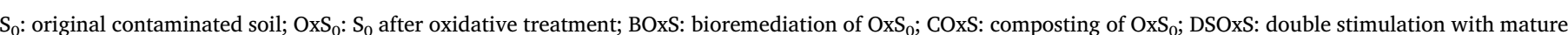
compost of $\mathrm{OxS}_{0}$.

nd: not detected.

For the same parameter, the mean values followed by different letters are significantly different $(p<.05)$. 
compost (DSOxS) evidenced a significant sulfate reduction.

Regarding the dilutive effect, no significant net total hydrocarbon elimination (respect to $\mathrm{OxS}_{0}$ ) was detected by $\mathrm{COxS}$ treatment. Nevertheless, a significant reduction in the 3-ring PAHs and short aliphatic chain hydrocarbon fractions $\left(\mathrm{C}_{9}-\mathrm{C}_{20}\right)$ were observed. As a result of this, a new hydrocarbon (PAHs and AHs) fraction profile was observed at the end of the treatment (Table 2).

An elimination of the $61 \%$ of the PAHs and $45 \%$ of the AHs was detected in DSOxS treatment. Only the PAHs removal exceeded the reduction expected by the dilution effect (51\%), and was produced at the expense of the 3-ring PAHs fraction. Although no net AHs removal was obtained by DSOxS treatment, a significant reduction in the short aliphatic chain hydrocarbon fractions $\left(\mathrm{C}_{9}-\mathrm{C}_{20}\right)$ was detected (Table 2 ).

The PAHs bioavailability increased significantly from $19 \%$ to $56 \%$ by COxS and to $54 \%$ by DSOxS at the end of the treatments (Table 2).

\subsection{Autochthonous PAHs potential degraders from the original soil}

RHD $\alpha-G N$ and RHD $\alpha$-GP sequences were obtained from DNA from the original sampled soil, $\mathrm{S}_{0}$. The RHD $\alpha$-GN sequences obtained showed 95\% similarity to the sequence corresponding to Gammaproteobacteria (Pseudomonas) while the RHD $\alpha$-GP sequences were identical to the ones of NidA3 gene of Corynebacteriales (Mycobacterium). These results were in agreement with the primer set designed by Cébron et al. (2008) for a large variety of GN and GP PAHs degraders, including Pseudomonas and Mycobacterium strains, genera which possess nahAc- and nidA/pdoA1like genes, respectively. The presence of PAH dioxygenase genes in both GN and GP bacteria highlights the potential PAH-degradation of autochthonous bacterial communities present in $\mathrm{S}_{0}$. Several articles have shown that members of Mycobacterium and Pseudomonas genera possess wide capacity to metabolize PAHs and have been extensively studied for their application in soil bioremediation (Smyth et al., 2010).

The accession numbers of the sequences of RHD $\alpha$ genes obtained by cloning are listed on Supplementary Material (S 3).

\subsection{Effect of the treatments on total bacterial population and PAHs potential degraders}

The $16 S$ rRNA gene copy numbers of total bacteria and PAH-RHD $\alpha$ genes from GP and GN PAH population of degraders were determined from the original soil $\left(\mathrm{S}_{0}\right)$, oxidized soil $\left(\mathrm{OxS}_{0}\right)$ and bioremediation control (BOxS) after 1, 6, 9 and 12 months (Fig. 1.A). The potential PAH degraders from COxS and DSOxS microcosms was analysed after the year of treatment (Fig. 1.B.).

$P A H-R H D \alpha-G N$ and $P A H-R H D \alpha-G P$ genes abundance in $\mathrm{S}_{0}$ represented about the $0.4 \%$ and $8 \%$ of the total $16 S$ rRNA copies $\mathrm{g}_{\mathrm{ds}}{ }^{-1}$, respectively, suggesting the intrinsic soil potential to PAHs elimination. Taking into account the results of $P A H-R H D \alpha$ genes obtained by cloning and the quantity of GN and GP PAH potential degraders, it is possible to assume the dominance of genes from Mycobacterium strains (phylum Actinobacteria) over the genes from Pseudomonas (phylum Proteobacteria) as PAHs degraders in $\mathrm{S}_{0}$.

As shown in Fig. 1.A, the oxidative treatment $\left(\mathrm{OxS}_{0}\right)$ produced a drastic decrease in the bacterial population, leaving a $24 \%$ of $16 S$ rRNA copies $\mathrm{g}_{\mathrm{ds}}{ }^{-1}$ in comparison with $\mathrm{S}_{0}$. Only copies from the $P A H-R H D \alpha-G P$ genes were detected.

In BOxS treatment, fluctuating values in the number of copies of the 16S rRNA gene was observed throughout the experiment (Fig. 1.A). However, sings of a gradual recovery of the $16 S$ rRNA copy numbers could be seen (after nine months the value exceeded the determined in $\mathrm{S}_{0}$ microcosms). The $P A H-R H D \alpha-G P$ genes number showed a gradual recovery during the incubation, reaching the $21 \%$ of the $16 S$ rRNA copy numbers after a year. The lower number of copies of $16 S$ rRNA gene and the significant recovery of the copy numbers of $P A H-R H D \alpha-G P$ genes resulted in an enrichment of $\mathrm{PAH}$ degrading bacteria after a year of treatment.
In COxS and DSOxS an increment of the 16S rRNA and PAH-RHD $\alpha$ $G P$ copies $g_{\mathrm{ds}}{ }^{-1}$ was observed after a year of treatment, up to values higher than those determined in $\mathrm{OxS}_{0}$ and in $\mathrm{BOxS}$ microcosms (Fig. 1.B). Contrary to the observation in BOxS microcosms, no enrichment in the GP PAH population of degraders was detected by composting strategies (COxS and DSOxS), GP PAH degrading population represented the $0.5 \%$ and $2 \%$ in COxS and DSOxS microcosms, respectively.

\subsection{Effect of the treatments on the microbial diversity and community structure}

Table 3 shows the result of pyrosequencing analysis from the soil microcosms after the treatments and from $S_{0}$ and the oxidized soil, $\mathrm{OxS}_{0}$. Pyrosequencing data analysis and subsequent statistical inference from $\mathrm{S}_{0}$ and from the soil microcosms after each treatment provided up to 133,611 sequences, which resulted in 98,334 useful $16 S$ rRNA sequences after the trimming process. The number of sequences for all treatments was normalized to the smallest number observed: 3745 sequences obtained from $\mathrm{OxS}_{0}$. Good's coverage of the prokaryotic diversity was $>94 \%$. Rarefaction curves were very near saturation, and showed the difference between the original contaminated soil, $\mathrm{S}_{0}$, and the soil microcosm samples after the treatments (Fig. S2).

Fig. 2 shows taxonomic profiles of the bacterial community at order level. The bacterial community from the contaminated soil $S_{0}$ was characterized by the dominance of member of Actinomycetales (34.2\%). The Actinomycetales order was represented by the Nocardioides and Actinophytocola genera with low presence of Mycobacterium (2.3\%).

A decrease in bacterial diversity with a remarkable reduction on species richness $\left({ }^{0} \mathrm{D}\right)$ was the result of the oxidative treatment in $\mathrm{OxS}_{0}$. The new bacterial community showed an uneven assemblage $\left({ }^{2} \mathrm{D}\right)$ with a few dominant species. The Pseudomonadales (62.4\%) and Bacillales (35.6\%) were the two predominant orders, represented by members of genera Acinetobacter and Bacillus, respectively. With or without organic amendments, the treatments applied (BOxS, COxS and DSOxS) allowed the recovery of richness and diversity of species reaching more even communities. The highest richness and diversity of species with an even arrangement of members was observed after the year of bioremediation treatment (BOxS microcosms). Members of genera Ohtaekwangia (22.4\%) and Acidobacteria Gp6 (11.1\%), and orders Actinomycetales $(10.7 \%)$ and Rhodospirillales (10.2\%) were the most abundant ones in BOxS microcosms.

In spite of the fact that the diversity indices of the $\mathrm{OxS}_{0}$ were recovered by soil composting ( $\mathrm{COxS}$ ) and mature compost addition (DSOxS), the values did not exceed those reached in BOxS. Members of Actinomycetales (23.4\%; 15.3\%), Rhizobiales (11.3\%; 12.9\%), Xanthomonadales $(10.2 \% ; 12.2 \%)$, Rhodospirillales $(8.9 \% ; 11.6 \%)$ and Gemmatimonadales $(8.8 \%$; $8.6 \%)$ represented the communities from COxS and DSOxS microcosms as the predominant orders, respectively.

The comparison among communities from DSOxS and COxS microcosms (Supplementary Material, Fig. S3) shows that class Gammaproteobacteria was significantly more abundant in DSOxS microcosms while members of Actinobacteria predominated in $\mathrm{COxS}$ microcosms. Members of the Bacteroidetes incertae-sedis class marked significant difference in DSOxS (8\%).

In order to understand the impact of treatments on bacterial diversity, canonical correspondence analysis (CCA) were used to determine the interaction among the soil properties and bacterial community structure (Fig. 3). The first two axes (CCA1 and CCA2) explaining the $62.7 \%$ of the total variance. The sulfate, AHs, OC, $\mathrm{pH}$ and OPR were the variables that significantly contributed to the biplot $(p<.05)$.

The OPR and residual sulfate were the most significant variables in $\mathrm{OxS}_{0}$ treatment that conditioned the establishment of a community mainly composed by Pseudomonadales and Bacillales orders.

The spatially close arrangement found between $S_{0}$ and BOxS 


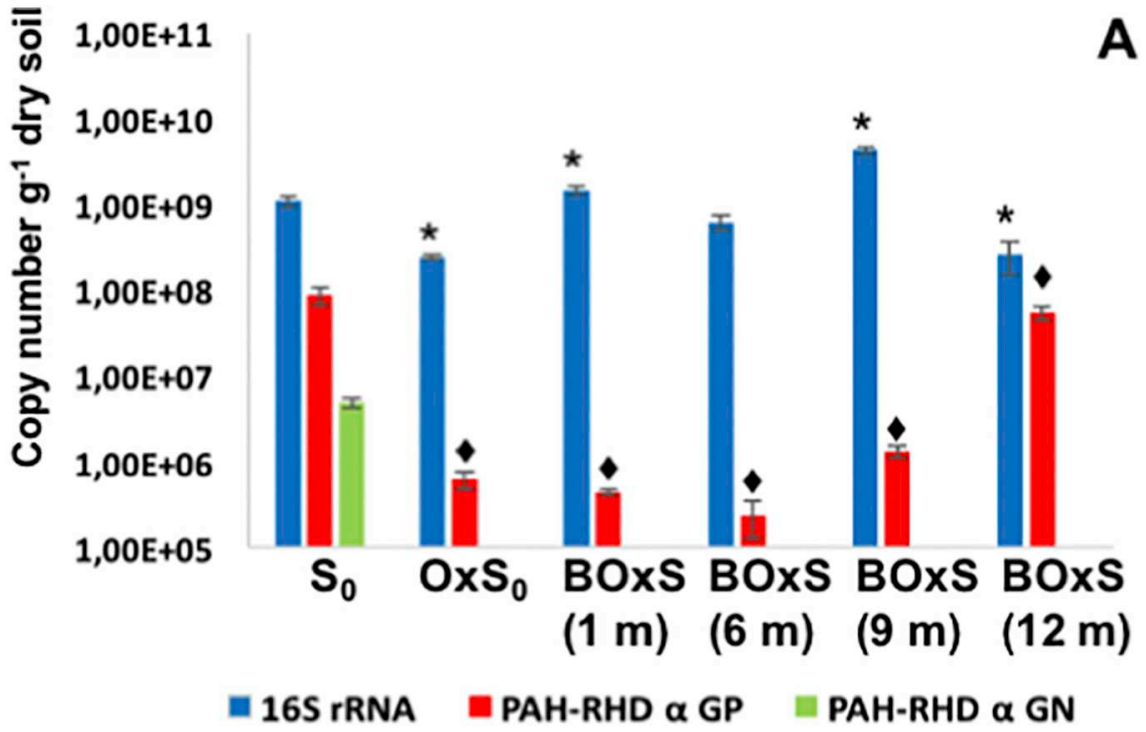

Fig. 1. Generalist and specialist population quantity. Copy number $\mathrm{g}^{-1}$ dry soil $16 S \mathrm{rRNA}, P A H-R H D \alpha-G N$ and $P A H$ - $R H D \alpha-G P$ genes for each treatment. The values significantly different at the $5 \%$ level (by the two-way ANOVA, Tukey test) compared with $\mathrm{S}_{0}$ are indicated with “*” for $16 S$ rRNA and with " $\diamond$ " for $P A H-R H D \alpha-G P$ genes. The absence of symbols indicates no significant difference $(p<.05)$. A: Quantification of genes before $\left(\mathrm{S}_{0}\right)$, after oxidation treatment $\left(\mathrm{OxS}_{0}\right)$ and along bioremediation treatment without organic amendment (BOxS). B: Quantification of genes before $\left(\mathrm{S}_{0}\right)$, after oxidation treatment $\left(\mathrm{OxS}_{0}\right)$ and at the end of treatments with or without organic amendment (COxS, DSOxS and BOxS).

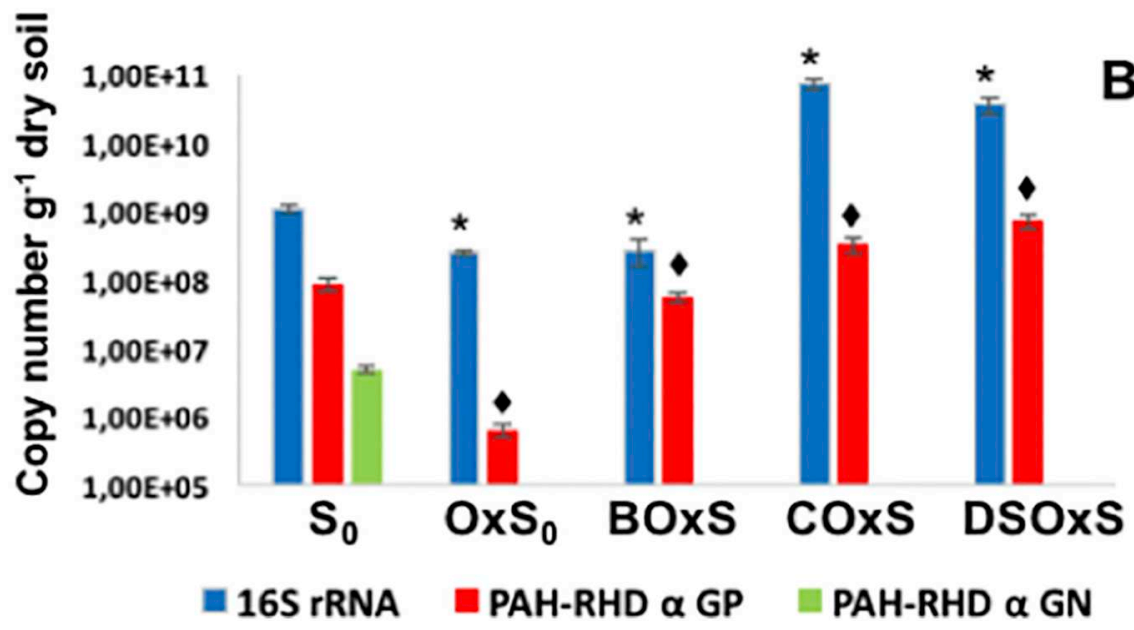

Table 3

Diversity parameters of the soil communities obtained by analysis of pyrosequencing from the microcosms at the end of the treatments.

\begin{tabular}{|c|c|c|c|c|c|}
\hline \multirow[t]{2}{*}{ Microcosms } & \multirow[t]{2}{*}{ Number of sequences } & \multirow[t]{2}{*}{ Observed OTUs } & \multicolumn{3}{|c|}{ Hill's numbers } \\
\hline & & & ${ }^{0} \mathrm{D}$ & ${ }^{1} \mathrm{D}$ & ${ }^{2} \mathrm{D}$ \\
\hline $\mathrm{S}_{0}$ & $6715 ; 6785 ; 4728$ & $435 \pm 9$ & $624 \pm 35$ & $70 \pm 2$ & $45 \pm 7$ \\
\hline $\mathrm{OxS}_{0}$ & $7762 ; 5899 ; 3745$ & $53 \pm 7$ & $90 \pm 26$ & $3 \pm 1$ & $3.1 \pm 0.5$ \\
\hline BOxS & $5415 ; 5478 ; 6422$ & $570 \pm 18$ & $815 \pm 72$ & $93 \pm 3$ & $77 \pm 14$ \\
\hline COxS & $7023 ; 7588 ; 9065$ & $420 \pm 13$ & $597 \pm 37$ & $75 \pm 1$ & $67 \pm 4$ \\
\hline DSOxS & $8227 ; 6498 ; 6984$ & $433 \pm 7$ & $621 \pm 12$ & $68 \pm 1$ & $36 \pm 1$ \\
\hline
\end{tabular}

Hill's numbers were calculated using a randomly selected subset of 3745 sequences per sample. Data are expressed as the mean \pm standard deviation of three replicated samples.

suggested the recovery of the bacterial community after the oxidative treatment, by means of coupled bioremediation treatment. The correlation with $\mathrm{AH}$ and $\mathrm{pH}$ variables suggested that members of the BOxS community such as Ohtaekwangia, Acidobacteria Gp6 and Rhodospirillales were associated with relative higher aliphatic hydrocarbon content and $\mathrm{pH}$.

The OC was the most significant variable that shaped the communities of the COxS and DSOxS treatments. Members of Sphingobacteriales, Rhodospirillales, Xanthomonadales, Rhizobiales, Gemmatimonadales, Alphaproteobacteria, Sphingomonadales and
Actinomycetales orders were associated with the treatments that applied organic amendments.

\section{Discussion}

The oxidative treatment of the chronically hydrocarbon contaminated soil with PS produced remarkable changes on the soil matrix, leading to the elimination of $29 \%$ of PAHs content and the rising of PAH bioavailability. In addition, the treatment produced an increase of twice in the DTC concentration as consequence of the unspecific soil organic 


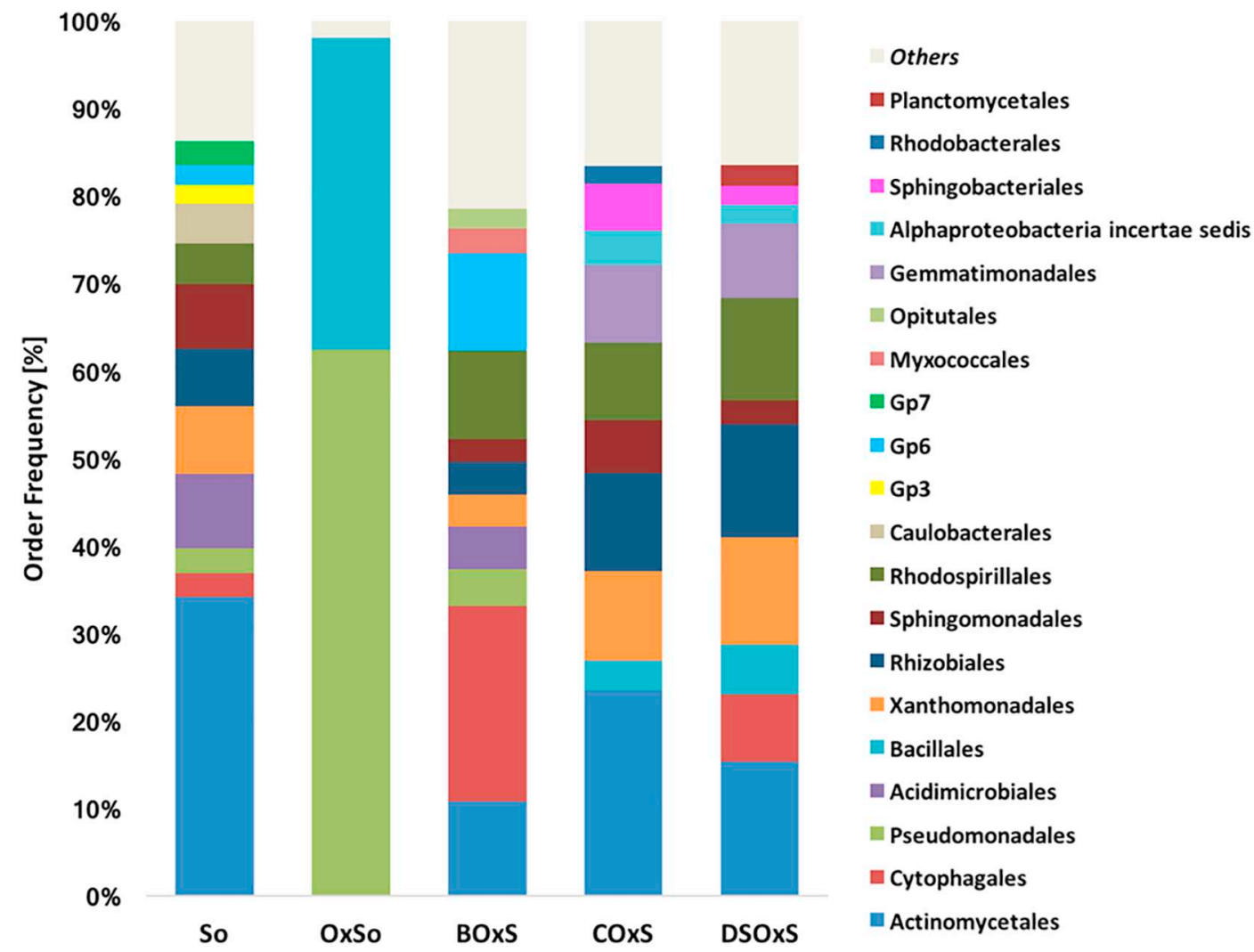

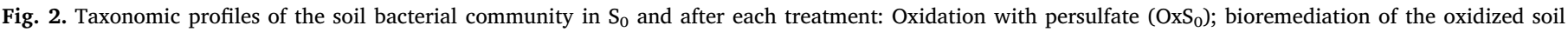

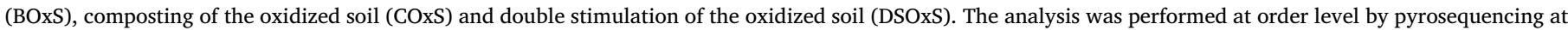
the end of the remediation treatment. Orders with abundance $<2 \%$ were grouped in "Others".

matter oxidation (Alexander, 2000; Oleszczuk, 2007). As it was expected, the PS treatment significantly increased the sulfate content with the decrease in the $\mathrm{pH}$ value in more than one order, although it remained close to neutrality.

The oxidative treatment also impacted on the soil bacterial populations, producing a significant decline in the $16 S$ rRNA gene copy numbers. Only the GP population harbouring the PAH-RHDa gene was detected, suggesting that the GP PAH population of degraders was more resistant to the oxidative stress than the GN PAH degrading population.

Others authors have studied the impact of applying persulfate on chronically contaminated soil, particularly on the generalist population (16S rRNA gene) and the specialist population alkB gene. Sutton et al. (2014a) reported that immediately after persulfate addition neither $16 \mathrm{~S}$ rRNA nor alkB genes were detected. The difference with our results could be due to the higher dose and the type of system (batch) applied by the authors. Richardson et al. (2011) applied a dose of PS similar to ours to the soil, and found a 2- to 3-log reduction in total bacterial $16 \mathrm{~S}$ rRNA genes, with the inhibition of the specialist phenanthrene-degraders population. All these findings suggest a differential resistance of the populations to PS exposure, and that the number of survivors depends on oxidant dosage and application procedure.

In addition to the reduction of $16 S$ rRNA gene copy numbers of total bacteria, a reduction in species richness was also observed, with an unequal arrangement of the bacterial community. The prevalence of Pseudomonadales and Bacillales immediately after oxidation suggests their resistance to oxidative treatment with PS. The CCA (Fig. 3) shows the association of the $\mathrm{OxS}_{0}$ community with a high sulfate concentration and an increase in redox potential, suggesting that members of the most abundant genera, Acinetobacter and Bacillus, were able to cope with oxidative stress in presence of high residual sulfate concentration. Members of the genera Acinetobacter and Bacillus have been isolated from a wide variety of habitats. Several strains have even thrived well in saline environmental condition similar to those imposed on the $\mathrm{OxS}_{0}$ (Fatajeva et al., 2014; Zuber, 2009). These populations may have played a pioneer role in the microbial soil recovery, by consuming the mobilized organic matter even under those environmentally adverse conditions.

As it was described in previous work (Medina et al., 2018), the combined bioremediation treatment in tandem (BOxS) promoted the nutrients mobilization from the matrix soil and an additional hydrocarbons elimination of PAHs (26\%) and AHs (66\%), suggesting that the remaining high concentration of sulfate did not prevent the biological activity. A 75\% DTC was consumed during bioremediation, leaving more complex and heavy organic compounds which is characteristic of mature organic matter (Rékási et al., 2019), as it is evidenced by the low $E_{4} / E_{6}$ ratio of the soil extracts after one year of treatment. Along with these results, the recovery of the bacterial population suggests that endogenous organic matter and available hydrocarbons promoted microbial degrading activity, with the consequent enrichment of PAH degrading bacteria. Sutton et al. (2014a) described the biologic utilization of mobilized nutrients during oxidative treatment and concluded that this fact conditioned the success of coupled bioremediation treatment. Contrarily to our results, the authors did not find significant biological activity after persulfate treatment, probably due to the high dose of oxidant applied. Using a soil column with a phenanthrene chronically contaminated soil, Richardson et al. (2011) reported a response pattern with a near-complete recovery of phenanthrene degraders after 30 days of persulfate injection. The authors argued that resilience might be a function of group-specific tolerance to oxidative conditions.

The BOxS treatment also led to the recovery of richness and diversity of species. Members of genera Ohtaekwangia and Acidobacteria Gp6, and orders Actinomycetales and Rhodospirillales were the most abundant. 


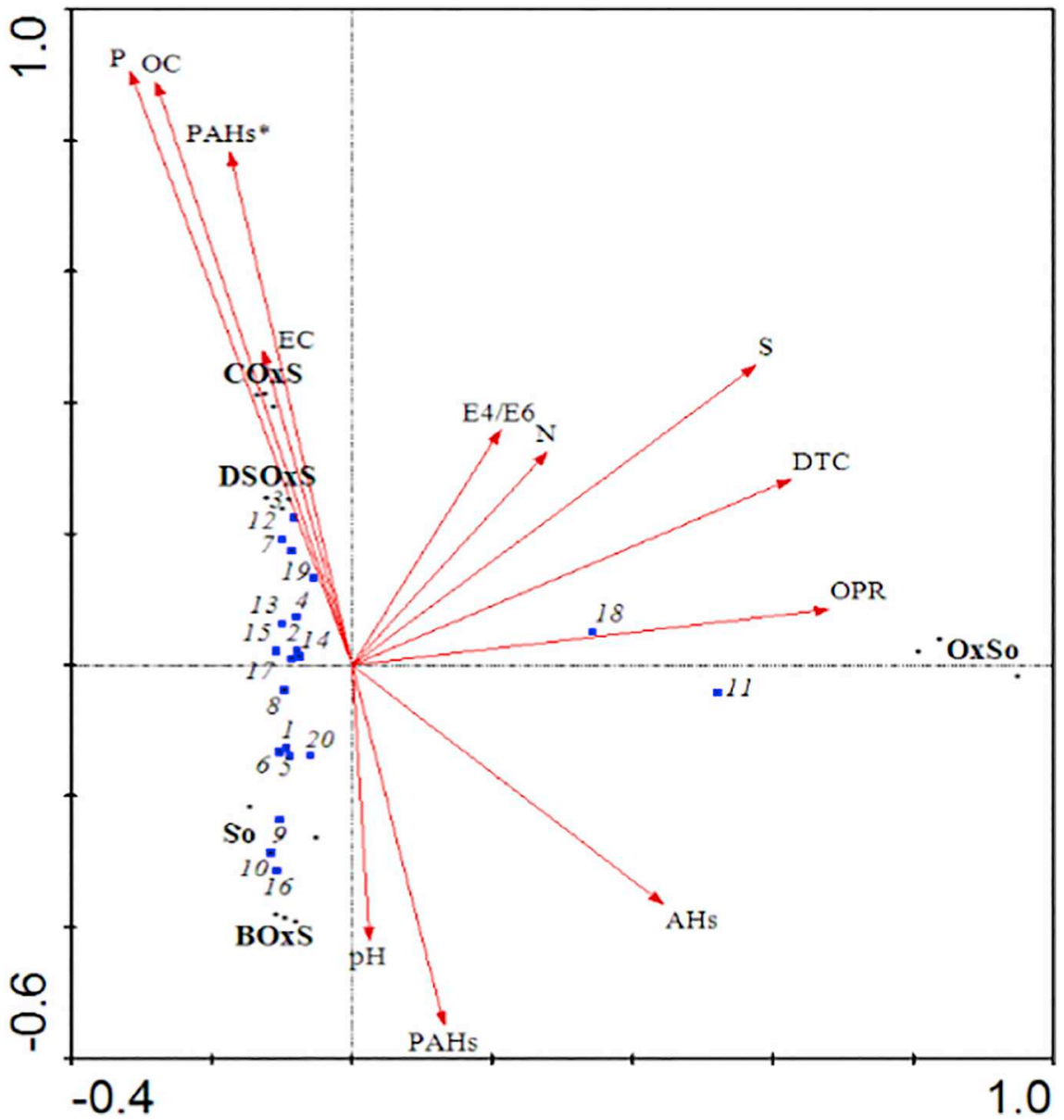

Fig. 3. Canonical correspondence analysis (CCA) plots representing first (CCA1) and second (CCA2) axis. The analysis was performed with different orders in all the treatments.

Orders used: 1: Othaekwangia; 2: Rhodospirillales; 3: Sphingobacteriales; 4: Rhizobiales; 5: Acidobacteria Gp6; 6: Acidimicrobiales; 7: Gemmatimonadales; 8: Myxococcales; 9: Opitutales; 10: Acidobacteria Gp7; 11: Pseudomonadales; 12: Alphaproteobacteria incertae sedis; 13: Xhandotomonadales; 14: Sphingomonadales; 15: Planctomycetales; 16: Acidobacteria Gp3; 17: Actinomycetales; 18: Bacillales; 19: Rodobacterales and 20: Caulobacterales.

Quantitative variables used: $\mathrm{pH}$, electrical conductivity (EC), redox potential (OPR), Organic carbon (OC), total nitrogen $(\mathrm{N})$, Dissolved Total Carbon (DTC), $\mathrm{E}_{4} / \mathrm{E}_{6}$ ratio $\left(E_{4} / E_{6}\right)$, available phosphorous $(P)$, sulfate content $(S)$, Bioavailable PAHs (PAHs*), total aliphatic hydrocarbon (AH), total PAH.
Ohtaekwangia as other members of Bacteroidetes phylum are gramnegative heterotrophic bacteria, which are common in ecosystems and are known to degrade high-molecular-weight organic compounds (Drury et al., 2013). Although the Ohtaekwangia's ecological role in the soil is still unclear, its abundance in hydrocarbon contaminated soils subjected to remediation treatments could assign it a specific petroleum degrading activity (Hou et al., 2015; Wang et al., 2016; Medina et al., 2018). Members of Acidobacteria have been reported as a slow-acting decomposer (Tian and Gao, 2014). The abundance of GN populations, such as Ohtaekwangia and Acidobacteria, in the BOxS treatment and the absence of the population of GN degraders harbouring PAH-RHD $\alpha$ genes suggest the active participation of these genera in the degradation of AHs and DTC consumption, both substrates available due to previous oxidative treatment. (Sutton et al., 2014b; Medina et al., 2018).

The combined COxS and DSOxS treatments produced different effects on the oxidized soil matrix. The composting with the oxidized soil matrix produced a partially humificated material, as suggested by the relative higher $\mathrm{E}_{4} / \mathrm{E}_{6}$ ratio and a significant consumption of DTC. Although changes in the profiles of relative abundance of the PAHs and AHs fractions could be associated with hydrocarbon degradation, the COxS treatment did not produced net hydrocarbon elimination (Table 3). Therefore, the significant reduction in DTC could be due to microbial activity involved in the transformation of organic matter which led to the preferential consumption of organic compounds easier to assimilate than hydrocarbons. This behaviour could also result in the lack of co-substrates, making the net elimination of hydrocarbons even less feasible (Dias et al., 2012; Sutton et al., 2014b).

On the other hand, the stimulation with mature compost in DSOxS promoted an effective PAHs elimination. The result could be explained by the high humification degree of the dissolved organic matter which promotes the solubilization of the PAHs into the humic acids pseudomicelles, enhancing the biodegradation (Smith et al., 2009).

The spatial disposition of the treatments observed in Fig. 3, where COxS and DSOxS appeared in opposite position respect to BOxS, would suggest that the organic amendment treatments effectively reduced the hydrocarbons content. However, taken into account the diluting effect of the added organic compounds, only DSOxS reduced significantly the PAHs content of the oxidized soil matrix $\left(\mathrm{OxS}_{0}\right)$.

Regardless of the treatments, the organic amendments promoted microbial development, surpassing the number of the total bacteria population and PAH degrading bacteria achieved by the bioremediation treatment, BOxS.

Sun et al. (2015) observed an increment of/in 16S rRNA copy number when supplying an agricultural soil with livestock manures. The authors observed that the addition of organic matter positively correlated with the nutritional status of the soil, preventing the loss of bacterial diversity with little effect on the indigenous soil bacterial community.

However, in the present work neither composting nor adding of mature compost led to the enrichment of PAH degraders. Notwithstanding these results, the higher proportion of GP PAH degrading bacteria achieved by the DSOxS treatment could be involved in the PAHs removal determined after one year. Working on an aged PAHs agricultural soil, Liu et al. (2019) observed the PAHs elimination by stimulation with humic acids and spent fungal substrate. Although the authors did not differentiate between GP and GN bacteria, they attributed the increase in the PAH degrading populations to the PAHs removal.

Noticeably, in the present work no treatment in tandem with the PS oxidation achieved the $P A H-R H D \alpha-G N$ gene copies recovery after one year of treatment, suggesting that this population was more sensitive to oxidative stress. The competition with the generalist population and the 
low representation in $\mathrm{S}_{0}$ could have also conditioned their recovery.

The composting and mature compost addition lend to the recovery of the diversity indices, promoting an increase in Proteobacteria. A higher ratio of Proteobacteria to Actinobacteria was observed in DSOxS (2.4), in comparison with the one observed in COxS (1.5), probably as the result of the nature and concentration of the available organic matter. The comparison among treatments showed that the class Gammaproteobacteria was significantly more abundant in DSOxS, while members of Actinobacteria predominated in COxS. According to Covino et al. (2016) the higher incidence of Actinobacteria is characteristic of the final stage of the composting treatment. Members of the Bacteroidetes incertae sedis class also marked significant difference between the treatments, being predominant in DSOxS (8\%). Their abundance suggests that the bacterial soil community would still have the potential to degrade hydrocarbons.

Although composting and the stimulation with mature compost are currently applied to the removal of soil organic contaminants, the effect of the organic substrates in the hydrocarbons elimination remains unclear. The fate and behaviour of PAHs in soil could be determined by factors such as the rate of sorption and sequestration, volatilization, leaching and degradation (Srogi, 2007). For example, the PAHs and their metabolic intermediaries can be bound to humic substances leading to the residue formation and subsequent humification (Smith et al., 2009; El Fels et al., 2016). Fu et al. (2018) showed that the dissolved black carbon, an important constitute of the dissolved organic matter pool, has significantly stronger binding affinity for non-polar organic compounds, as compared with humic substances. On the other hand, as demonstrated by Tejeda-Agredano et al. (2014), the humic substances could inhibit or stimulate the PAHs biodegradation depending on their availability in the soil. Recently, Zhu et al. (2019) showed that the lignin-containing substrates could promote the formation of bound residues in humic acid, but also the mineralization of benz $[a]$ anthracene by co-metabolism with lignin degradation.

From our results, neither the binding to humic acids nor the mineralization would have been dominant processes during the treatments. The fact that the organic amendments promoted the content of bioavailable PAH suggests their release from the soil matrix. This behaviour and the higher increase of the density of PAH degraders than in the control BOxS suggests that these are not the only factors that influence hydrocarbon degradation in the presence of exogenous organic matter. For instance, a preferential assimilation of organic amendments by the microbial community could be one of the reasons that explains the low efficiency of hydrocarbon removal during one year of treatment.

Even though the reductive sulfate assimilation was promoted during the combined treatments, the high EC and the residual sulfate could produce negative effects on soil quality, such as phytotoxic effect. In addition, the high bioavailable content of PAHs after the one-year treatment will require careful long-term monitoring to verify the reduction of environmental risks.

On the other hand, the increased humification evidenced by stimulation with mature compost of the oxidized soil could result in greater enzymes immobilization in the humic colloid (Lucas et al., 2018), promoting the soil fertility. Similar behaviour could be expected with long-term composting (COxS).

Notwithstanding the evident recovery of bacterial diversity and PAH degrading potential, further studies will be necessary to determine the fate of the PAH during the treatments, and thus make composting strategies reliable to recover the soil fertility and productivity from preoxidized soil chronically contaminated with PAHs.

\section{Conclusions}

In this study, the effect of composting and of the addition of mature compost in tandem with persulfate treatment in a soil chronically contaminated with hydrocarbons was evaluated, mainly focusing on the elimination of hydrocarbons and the recovery of potentially PAHs degrading bacterial populations.

The persulfate treatment achieved significant elimination of PAHs and increased the PAH bioavailability and soil nutrients. The coupled composting strategies were effective in recovering generalist and GP PAH degrading populations. The absence of the GN PAH degrader could be associated with greater sensitivity to treatment with PS and less competitive capacity. Nonetheless, only the stimulation with mature compost produced PAHs removal. We attribute the low efficiency in part to the preferential consumption of more easily degradable compounds than hydrocarbons. However, we cannot rule out that hydrocarbon degradation activity occurred during the treatments, possibly promoting the formation of bound residues, but also the release of PAHs from the soil matrix, resulting into a low or absence of net hydrocarbon elimination. Therefore, more research on the interactions between PAHs and organic matter, the removal mechanisms and toxicity are needed to optimize the efficiency of the composting strategies on preoxidized chronically contaminated soil.

Supplementary data to this article can be found online at https:// doi.org/10.1016/j.apsoil.2019.103459.

\section{Acknowledgments}

Rocío Medina has a doctoral fellowship supported by CONICET and Antonio José Fernández-González was awarded with a postdoctoral contract from RECUPERA 2020.

\section{Funding sources}

This research was partially supported by the Agencia Nacional de Promoción Científica y Tecnológica (PICT 2010-00366), PIO 20142015-13320130100005CO and Jefatura de Gabinete de Ministros by Bec.Ar program. The work developed at Estación Experimental del Zaidín (CSIC) was funded by project 20134R069 (RECUPERA 2020) from the Spanish Ministry of Economy and Competitiveness and CSIC, including European Regional Development Fund. Rocío Medina has a doctoral fellowship supported by CONICET and Antonio José Fernández-González was awarded with a postdoctoral contract from RECUPERA 2020.

\section{Author contributions}

Conceptualization: R.M, A.J.F.G, J.A.R, M.F.L, M.T.D.P; Data curation: R.M, A.J.F.G; Formal Analysis: R.M, A.J.F.G, F.M.G.R, J.A.R, M.F.L, M.T.D.P; Funding Acquisition: J.A.R, M.F.L, M.T.D.P; Investigation: R.M, J.A.R, M.F.L, M.T.D.P; Methodology: R.M, A.J.F.G, F.M.G.R, P.J.V, J.A.R, M.F.L, M.T.D.P; Project Administration: M.F.L, M.T.D.P; Resources: J.A.R, M.F.L, M.T.D.P; Supervision: J.A.R, M.F.L, M.T.D.P; Visualization R.M, J.A.R; M.T.D.P; Roles/Writin - original draft R.M, M.T.D.P; Writing - review \& editing A.J.F.G, F.M.G.R, P.J.V, J.A.R, M.F.L, M.T.D.P.

\section{Declaration of competing interest}

The authors declare no conflict of interest.

\section{References}

Alexander, M., 2000. Aging, bioavailability, and overestimation of risk from environmental pollutants. Environ. Sci. Technol. 34, 4259-4265. https://doi.org/10.1021/ es001069+.

Antízar-Ladislao, B., Lopez-Real, J., Beck, A.J., 2006. Investigation of organic matter dynamics during in-vessel composting of an aged coal-tar contaminated soil using fluorescence excitation-emission spectroscopy. Chemosphere 64 (5), 839-847. https://doi.org/10.1016/j.chemosphere.2005.10.036.

Bajagain, R., Lee, S., Jeong, S.W., 2018. Application of persulfate-oxidation foam spraying as a bioremediation pretreatment for diesel oil-contaminated soil. Chemosphere 207, 565-572. https://doi.org/10.1016/j.chemosphere.2018.05.081. 
Baker, G.C., Smith, J.J., Cowan, D., 2003. A review and re-analysis of domain-specific $16 \mathrm{~S}$ primers. J. Microbiol. Methods 55, 541-555. https://doi.org/10.1016/j.mimet.2003. 08.009.

Cai, Q.Y., Mo, C.H., Wu, Q.T., Zeng, Q.Y., Katsoyiannis, A., Férard, J.F., 2007. Bioremediation of polycyclic aromatic hydrocarbons (PAHs)-contaminated sewage sludge by different composting processes. J. Hazard. Mater. 142, 535-542. https:// doi.org/10.1016/j.jhazmat.2006.08.062.

Cébron, A., Norini, M.P., Beguiristain, T., Leyval, C., 2008. Real-time PCR quantification of $\mathrm{PAH}$-ring hydroxylating dioxygenase (PAH-RHD $\alpha$ ) genes from gram positive and gram negative bacteria in soil and sediment samples. J. Microbiol. Methods 73, 148-159. https://doi.org/10.1016/j.mimet.2008.01.009.

Cébron, A., Faure, P., Lorgeoux, C., Ouvrard, S., Leyval, C., 2013. Experimental increase in availability of a PAH complex organic contamination from an aged contaminated soil: consequences on biodegradation. Environ. Pollut. 177, 98-105. https://doi.org/ 10.1016/j.envpol.2013.01.043.

Chao, A., Chiu, C.H., Hsieh, T.C., Inouye, B.D., 2012. Proposing a resolution to debates on diversity partitioning. Ecology 93, 2037-2051. https://doi.org/10.1890/11-1817.1.

Cipullo, S., Negrin, I., Claveau, L., Snapir, B., Tardif, S., Pulleyblank, C., Prpich, G., Campo, P., Coulon, F., 2019. Linking bioavailability and toxicity changes of complex chemicals mixture to support decision making for remediation endpoint of contaminated soils. Sci. Total Environ. 650, 2150-2163. https://doi.org/10.1016/j. scitotenv.2018.09.339.

Covino, S., Fabianová, T., Křesinová, Z., Čvančarová, M., Burianová, E., Filipová, A., Vořísková, J., Baldrian, P., Cajthaml, T., 2016. Polycyclic aromatic hydrocarbon degradation and microbial community shifts during co-composting of creosotetreated wood. J. Hazard. Mat. 301, 17-26. https://doi.org/10.1016/j.jhazmat.2015. 08.023.

Curiel-Yuste, Barba, J., Fernandez-Gonzalez, A.J., Fernandez-Lopez, M., Mattana, S., Martinez-Vilalta, J., Nolis, P., Lloret, F., 2012. Changes in soil bacterial community triggered by drought-induced gap succession preceded changes in soil C stocks and quality. Ecology and Evolution 2, 3016-3031. https://doi.org/10.1002/ece3.409.

Dias, R.L., Ruberto, L., Hernández, E., Vázquez, S.C., Balbo, A.L., Del Panno, M.T., Mac Cormack, W.P., 2012. Bioremediation of an aged diesel oil-contaminated Antarctic soil: evaluation of the 'on site' biostimulation strategy using different nutrient sources. Int. Biodeterior. Biodegrad. 75, 96-103. https://doi.org/10.1016/j.ibiod. 2012.07.020.

Drury, B., Rosi-Marshall, E., Kelly, J.J., 2013. Wastewater treatment effluent reduces the abundance and diversity of benthic bacterial communities in urban and suburban rivers. Appl. Environ. Microbiol. 79, 1897-1905. https://doi.org/10.1128/AEM. 03527-12.

El Fels, L., Lemee, L., Ambles, A.M., 2016. Identification and biotransformation of aliphatic hydrocarbons during co-composting of sewage sludge-date palm waste using pyrolysis-GC/MS technique. Environ. Sci. Pollut. Res. 23, 16857-16864. https://doi. org/10.1007/s11356-016-6670-9.

Fatajeva, E., Gailiūtè, I., Paliulis, D., Grigiškis, S., 2014. The use of Acinetobacter sp. for oil hydrocarbon degradation in saline waters. Biologija 60 (3), 126-133. https://doi. org/10.6001/biologija.v60i3.2971.

Fernández-González, A.J., Martínez-Hidalgo, P., Cobo-Díaz, J.F., Villadas, P.J., MartínezMolina, E., Toro, N., Fernández-López, M., 2017. The rhizosphere microbiome of burned holm-oak: potential role of the genus Arthrobacter in the recovery of burned soils. Sci. Rep. 7, 6008. https://doi.org/10.1038/s41598-017-06112-3.

Fetzer, J.C., 2007. The chemistry and analysis of large PAHs. Polycycl. Aromat. Compd. 27 (2), 143-162. https://doi.org/10.1080/10406630701268255.

Fu, H., Wei, C., Qu, X., Li, H., Zhu, D., 2018. Strong binding of apolar hydrophobic organic contaminants by dissolved black carbon released from biochar: a mechanism of pseudomicelle partition and environmental implications. Environ. Pollut. 232, 402-410. https://doi.org/10.1016/j.envpol.2017.09.053.

Hall, T.A., 1999. BioEdit: A user-friendly biological sequence alignment editor and analysis program for Windows 95/98/NT. In: Nucleic Acids Symposium Series. 41. Information Retrieval Ltd., c1979-c2000, London, pp. 95-98. http://jwbrown.mbio. ncsu.edu/JWB/papers/1999Hall1.pdf.

Hill, M.O., 1973. Diversity and evenness: a unifying notation and its consequences. Ecology 54, 427-432. https://doi.org/10.2307/1934352.

Hou, J., Liu, W., Wang, B., Wang, Q., Luo, Y., Franks, A.E., 2015. PGPR enhanced phytoremediation of petroleum contaminated soil and rhizosphere microbial community response. Chemosphere 138, 592-598. https://doi.org/10.1016/j.chemosphere. 2015.07.025.

Huling, S.G., Pivetz, B.E., 2006. In-situ Chemical Oxidation. EPA/600/R-06/072. United States Environmental Protection Agency, Cincinnati, Ohio. http://www.dtic.mil/ dtic/tr/fulltext/u2/a507297.pdf.

Ilani, T., Schulz, E., Chefetz, B., 2005. Interactions of organic compounds with wastewater dissolved organic matter. J. Environ. Qual. 34 (2), 552-562. https://doi.org/10. 2134/jeq2005.0552.

Jednak, T., Avdalović, J., Miletić, S., Slavković-Beškoski, L., Stanković, D., Milić, J., Beškoski, V., Gojgić-Cvijović, G., Vrvića, M.M., 2017. Transformation and synthesis of humic substances during bioremediation of petroleum hydrocarbons. Int. Biodeterior. Biodegrad. 122, 47-52. https://doi.org/10.1016/j.ibiod.2017.04.009.

Jost, L., 2006. Entropy and diversity. Oikos 113, 363-375. https://doi.org/10.1111/j. 2006.0030-1299.14714 x.

Kakosová, E., Hrabák, P., Černík, M., Novotný, V., Czinnerová, M., Trögl, J., Popelka, J., Kuráň, P., Zoubková, L., Vrtoch, L., 2017. Effect of various chemical oxidation agents on soil microbial communities. Chem. Eng. J. 314, 257-265. https://doi.org/10. 1016/j.cej.2016.12.065.

Lemaire, J., Laurent, F., Leyval, C., Schwartz, C., Buès, M., Simonnot, M.O., 2013. PAH oxidation in aged and spiked soils investigated by column experiments. Chemosphere 91 (3), 406-414. https://doi.org/10.1016/j.chemosphere.2012.12.003.
Liang, C.J., Bruell, C.J., Marley, M.C., Sperry, K.L., 2003. Thermally activated persulfate oxidation of trichloroethylene (TCE) and 1, 1, 1-trichloroethane (TCA) in aqueous systems and soil slurries. Soil Sediment Contam. Int. J. 12, 207-228. https://doi.org/ 10.1080/713610970.

Liao, X., Liu, Q., Li, Y., Gong, X., Cao, H., 2019. Removal of polycyclic aromatic hydrocarbons from different soil fractions by persulfate oxidation. J. Environ. Sci. 78 , 239-246. https://doi.org/10.1016/j.jes.2018.10.001.

Liu, X., Ge, W., Zhang, X., Chai, C., Wu, J., Xiang, D., Chen, X., 2019. Biodegradation of aged polycyclic aromatic hydrocarbons in agricultural soil by Paracoccus $s p$. LXC combined with humic acid and spent mushroom substrate. J. Hazard. Mater., 120820. https://doi.org/10.1016/j.jhazmat.2019.120820.

Lominchar, M.A., Lorenzo, D., Romero, A., Santos, A., 2017. Remediation of soil contaminated by PAHs and TPH using alkaline activated persulfate enhanced by surfactant addition at flow conditions. J. Chem. Technol. Biotechnol. 93, 1270-1278. https://doi.org/10.1002/jctb.5485.

Lucas, E.G., Izquierdo, C.G., Fernández, M.T.H., 2018. Changes in humic fraction characteristics and humus-enzyme complexes formation in semiarid degraded soils restored with fresh and composted urban wastes. A 5-year field experiment. J. Soils Sediments 18 (4), 1376-1388. https://doi.org/10.1007/s11368-016-1537-8.

Medina, R., David Gara, P.M., Fernández-González, A.J., Rosso, J.A., Del Panno, M.T 2018. Remediation of a soil chronically contaminated with hydrocarbons through persulfate oxidation and bioremediation. Sci. Total Environ. 618, 518-530. https:// doi.org/10.1016/j.scitotenv.2017.10.326.

Mora, V.C., Rosso, J.A., Carrillo Le Roux, G., Mártire, D.O., Gonzalez, M.C., 2009 Thermally activated peroxydisulfate in the presence of additives: a clean method for the degradation of pollutants. Chemosphere 75 (10), 1405-1409. https://doi.org/10. 1016/j.chemosphere.2009.02.038.

Mora, V.C., Madueño, L., Peluffo, M., Rosso, J.A., Del Panno, M.T., Morelli, I.S., 2014. Remediation of phenanthrene-contaminated soil by simultaneous persulfate chemical oxidation and biodegradation processes. Environ. Sci. Pollut. Res. 21, 7548-7556. https://doi.org/10.1007/s11356-014-2687-0.

Oleszczuk, P., 2007. Investigation of potentially bioavailable and sequestrated forms of polycyclic aromatic hydrocarbons during sewage sludge composting. Chemosphere 70, 288-297. https://doi.org/10.1016/j.chemosphere.2007.06.011.

Osgerby, I.T., 2006. ISCO technology overview: do you really understand the chemistry? In: Contaminated Soils, Sediments and Water. Success and Challenges Springer, Boston, MA, pp. 287-308. https://doi.org/10.1007/0-387-28324-2 19.

Peluffo, M., Mora, V.C., Morelli, I.S., Rosso, J.A., 2018. Persulfate treatments of phenanthrene-contaminated soil: effect of the application parameters. Geoderma 317, 8-14. https://doi.org/10.1016/j.geoderma.2017.12.016.

Rékási, M., Mazsu, N., Draskovits, E., Bernhardt, B., Szabó, A., Rivier, P.A., Farkas, C. Borsány, B., Pirkó, B., Molnár, S., Kátay, G., Uzinger, N., 2019. Comparing the agrochemical properties of compost and vermicomposts produced from municipal sewage sludge digestate. Bioresour. Technol. 291, 121861. https://doi.org/10.1016/ j.biortech.2019.121861.

Richardson, S.D., Lebron, B.L., Miller, C.T., Aitken, M.D., 2011. Recovery of phenanthrene-degrading bacteria after simulated in situ persulfate oxidation in contaminated soil. Environ. Sci. Technol. 45, 719-725. https://doi.org/10.1021/ es102420r.

Rodríguez-Eugenio, N., McLaughlin, M., Pennock, D., 2018. Soil Pollution: A Hidden Reality. FAO978-92-5-130505-8.

Sanger, F., Nicklen, S., Coulson, A.R., 1977. DNA sequencing with chain-terminating inhibitors. Proc. Natl. Acad. Sci. U. S. A. 74, 5463-5467. https://doi.org/10.1073/ pnas.74.12.5463.

Satapanajaru, T., Chokejaroenrat, C., Sakulthaew, C., Yoo-iam, M., 2017. Remediation and restoration of petroleum hydrocarbon containing alcohol-contaminated soil by persulfate oxidation activated with soil minerals. Water Air Soil Pollut. 228, 345. https://doi.org/10.1007/s11270-017-3527-x.

Sayara, T., Sarrà, M., Sánchez, A., 2009. Preliminary screening of co-substrates for bioremediation of pyrene-contaminated soil through composting. J. Hazard. Mater. 172, 1695-1698. https://doi.org/10.1016/j.jhazmat.2009.07.142.

Sayara, T., Sarrà, M., Sánchez, A., 2010. Effects of compost stability and contaminant concentration on the bioremediation of PAHs-contaminated soil through composting. J. Hazard. Mater. 179, 999-1006. https://doi.org/10.1016/j.jhazmat.2010.03.104.

Scelza, R., Rao, M.A., Gianfreda, L., 2008. Response of an agricultural soil to pentachlorophenol (PCP) contamination and the addition of compost or dissolved organic matter. Soil Biol. Biochem. 40, 2162-2169. https://doi.org/10.1016/j.soilbio.2008. 05.005.

Schloss, P.D., Westcott, S.L., Ryabin, T., Hall, J.R., Hartmann, M., Hollister, E.B., Lesniewski, R.A., Oakley, B.B., Parks, D.H., Robinson, C.J., Sahl, J.W., Stres, B., Thallinger, G.G., Van Horn, D.J., Weber, C.F., 2009. Introducing mothur: opensource, platform-independent, community-supported software for describing and comparing microbial communities. Appl. Environ. Microbiol. 75, 7537-7541. https://doi.org/10.1128/AEM.01541-09.

Smith, K. E; Thullner, M; Wick, L. Y; Harms, H., 2009. Sorption to humic acids enhances polycyclic aromatic hydrocarbon biodegradation. Environ. Sci. Technol. 43(19), 7205-7211. doi.org/https://doi.org/10.1021/es803661s.

Smyth, T.J., Perfumo, A., McClean, S., Marchant, R., Banat, I.M., 2010. Isolation and analysis of lipopeptides and high molecular weight biosurfactants. In: Handbook of Hydrocarbon and Lipid Microbiology. Springer Berlin Heidelberg, pp. 3687-3704. https://doi.org/10.1007/978-3-540-77587-4_290.

Sparks, D.L., 1996. Methods of Soil Analysis, Chemical Methods. (USA. Madison, WI (Ed.) 631.417/S736 V.3).

Srogi, K., 2007. Monitoring of environmental exposure to polycyclic aromatic hydrocarbons: a review. Environ. Chem. Lett. 5 (4), 169-195. https://doi.org/10.1007/ s10311-007-0095-0. 
Suman, S., Sinha, A., Tarafdar, A., 2016. Polycyclic aromatic hydrocarbons (PAHs) concentration levels, pattern, source identification and soil toxicity assessment in urban traffic soil of Dhanbad, India. Sci. Total Environ. 545, 353-360. https://doi.org/10. 1016/j.scitotenv.2015.12.061.

Sun, R., Zhang, X.X., Guo, X., Wang, D., Chu, H., 2015. Bacterial diversity in soils subjected to long-term chemical fertilization can be more stably maintained with the addition of livestock manure than wheat straw. Soil Biol. Biochem. 88, 9-18. https:// doi.org/10.1016/j.soilbio.2015.05.007.

Sutton, N.B., Grotenhuis, T.C., Langenhoff, A.A.M., Rijnaarts, H.H.M., 2011. Efforts to improve coupled in situ chemical oxidation with bioremediation: a review of optimization strategies. J. Soils Sediments 11, 129-140. https://doi.org/10.1007/ s11368-010-0272-9.

Sutton, N.B., Langenhoff, A.A., Lasso, D.H., van der Zaan, B., van Gaans, P., Maphosa, F., Smidt, H., Grotenhuis, T., Rijnaarts, H.H., 2014a. Recovery of microbial diversity and activity during bioremediation following chemical oxidation of diesel contaminated soils. Appl. Microbiol. Biotechnol. 98, 2751-2764. https://doi.org/10.1007/s00253013-5256-4.

Sutton, N.B., Grotenhuis, T.C., Rijnaarts, H.H.M., 2014b. Impact of organic carbon and nutrients mobilized during chemical oxidation on subsequent bioremediation of a diesel-contaminated soil. Chemosphere 97, 64-70. https://doi.org/10.1016/j. chemosphere.2013.11.005.

Swift, R.S., 1996. Organic matter characterization. In: Methods of Soil Analysis Part 3-Chemical Methods, (methodsofsoilan3), pp. 1011-1069.

Tejeda-Agredano, M.C., Mayer, P., Ortega-Calvo, J.J., 2014. The effect of humic acids on biodegradation of polycyclic aromatic hydrocarbons depends on the exposure regime. Environ. Pollut. 184, 435-442. https://doi.org/10.1016/j.envpol.2013.09.031.

Tian, Y., Gao, L., 2014. Bacterial diversity in the rhizosphere of cucumbers grown in soils covering a wide range of cucumber cropping histories and environmental conditions. Microb. Ecol. 68, 794-806. https://doi.org/10.1007/s00248-014-0461-y.
Tsitonaki, A., Petri, B., Crimi, M., Mosbæk, H., Siegrist, R.L., Bjerg, P.L., 2010. In situ chemical oxidation of contaminated soil and groundwater using persulfate: a review. Crit. Rev. Environ. Sci. Technol. 40, 55-91. https://doi.org/10.1080/ 10643380802039303

Valderrama, C., Alessandri, R., Aunola, T., Cortina, J.L., Gamisans, X., Tuhkanen, T., 2009. Oxidation by Fenton's reagent combined with biological treatment applied to creosote-comtaminated soil. J. Hazard. Mater. 166, 594-602. https://doi.org/10. 1016/j.jhazmat.2008.11.108.

Villadas, P.J., Fernández-López, M., Ramírez-Saad, H., Toro, N., 2007. Rhizosphere-bacterial community in Eperua falcata (Caesalpiniaceae) a putative nitrogen-fixing tree from French Guiana rainforest. Microb. Ecol. 53, 317-327. https://doi.org/10.1007/ s00248-006-9158-1.

Wang, L., Yang, F., Yuan, J., Raza, W., Huang, Q., Shen, Q., 2016. Long-term application of bioorganic fertilizers improved soil biochemical properties and microbial communities of an apple orchard soil. Front. Microbiol. 7, 1-12. https://doi.org/10. 3389/fmicb.2016.01893.

Wang, C.H., Wu, S.H., Zhou, S.L., Shi, Y.X., Song, J., 2017. Characteristics and source identification of polycyclic aromatic hydrocarbons (PAHs) in urban soils: a review. Pedosphere 27 (1), 17-26.

Zhou, Z., Liu, X., Sun, K., Lin, C., Ma, J., He, M., Ouyang, W., 2019. Persulfate-based advanced oxidation processes (AOPs) for organic contaminated soil remediation: a review. Chem. Eng. J. 372, 836-851. https://doi.org/10.1016/j.cej.2019.04.213.

Zhu, Q., Wu, Y., Zeng, J., Zhang, T., Lin, X., 2019. Influence of organic amendments used for benz [a] anthracene remediation in a farmland soil: pollutant distribution and bacterial changes. J. Soils Sediments 1-10. https://doi.org/10.1007/s11368-01902368-6.

Zuber, P., 2009. Management of oxidative stress in Bacillus. Annu. Rev. Microbiol. 63, 575-597. https://doi.org/10.1146/annurev.micro.091208.073241. 